\title{
Wybrane problemy klasyfikacji penitencjarnej w percepcji personelu specjalistycznego
}

\author{
ADAM KWIECIŃSKI \\ ORCID: 0000-0002-2652-2689 \\ Katedra Prawa Karnego Wykonawczego \\ Wydział Prawa, Administracji i Ekonomii Uniwersytetu Wrocławskiego
}

Poszukiwanie optymalnych mechanizmów prawnych dla rozlokowania w zakładach karnych osób skazanych na karę pozbawienia wolności pozostaje w centrum zainteresowania penitencjarystów na całym świecie. Taka sytuacja ma w zasadzie miejsce od momentu uznania, iż kara pozbawienia wolności może realizować inne społecznie użyteczne funkcje oprócz retrybutywnej, a więzienia nie muszą być jedynie miejscami odosobnienia dla osób, które miałyby trwale pozostawać poza nawiasem społeczeństwa. Równolegle dostrzeżono, iż przy odpowiedniej organizacji instytucji penitencjarnych i właściwym rozmieszczeniu w nich skazanych można osiągnąć znacznie lepsze wyniki na polu społecznej readaptacji. Niejednokrotnie zależność ta jest stawiana znacznie bardziej stanowczo właściwie przeprowadzona klasyfikacja uważana jest wtedy za warunek sine qua non podejmowania jakiejkolwiek działalności wychowawczej więziennictwa.

Wydawać by się mogło, iż dyskurs w tym obszarze powinien tracić na sile w miarę doskonalenia form i metod oddziaływania na skazanych. Tak się jednak nie stało. Wraz z rozwojem form indywidualizacji penitencjarnej w miejscu rozwiązanych problemów klasyfikacyjnych pojawiały 
się nowe. Wydzielenie i ustalenie potrzeby odrębnego postępowania dla coraz to nowych grup skazanych skutkowało sporami, których temperatura niejednokrotnie świadczyła o głębokiej polaryzacji poglądów nie tylko w środowisku nauki, lecz także w gronie praktyków, a nawet w opinii społecznej. Doskonałym przykładem niech będzie dyskusja tocząca się wokół kwestii rozmieszczenia w zakładach karnych skazanych uzależnionych, nosicieli wirusa HIV, skazanych z zaburzeniami preferencji seksualnych czy osadzonych, których zwykło się określać mianem „niebezpiecznych". Z tego względu podejmowanie w badaniach naukowych tematyki klasyfikacji penitencjarnej należy uznać za pożądane, a problemy występujące na tym tle z pewnością nadal kwalifikują się do istotnych dla prawidłowego funkcjonowania systemu penitencjarnego.

W ramach niniejszego opracowania zaprezentowane zostaną wyniki ogólnopolskich badań zrealizowanych wśród personelu specjalistycznego jednostek penitencjarnych w latach 2016-2017. Były one częścią szerokiego projektu badawczego poświęconego analizie wykonywania kary pozbawienia wolności w systemie terapeutycznym ${ }^{1}$. W badaniach tych wzięło udział 371 specjalistów (psychologów, lekarzy, pedagogów, terapeutów) zatrudnionych w ośrodkach diagnostycznych oraz oddziałach terapeutycznych o różnej specjalizacji. Spora grupa pytań zawartych w kwestionariuszu ankietowym dotyczyła kwestii klasyfikacyjnych. Wydaje się, że z racji wiedzy i doświadczenia respondentów w tym zakresie kwestie te zasługują na wydzielenie i odrębne omówienie. Niniejszy tekst będzie zatem służyć prezentacji poglądów i opinii kluczowej z punktu widzenia tematu części personelu więziennego.

Pierwsze z pytań odnoszących się do klasyfikacji dotyczyło tego, jak powinna wyglądać procedura kwalifikacji skazanych do właściwego systemu wykonywania kary pozbawienia wolności. Odwołując się do doświadczenia zawodowego respondentów, poproszono ich o wskazanie organu, który w ich ocenie byłby najwłaściwszy do wydania tak zwanej wstępnej (pierwszej) decyzji klasyfikacyjnej. Co istotne, oprócz istniejących w obowiązującym porządku prawnym mechanizmów zaproponowano także nowe. Propozycje te zamieszczono w kwestionariuszu badawczym w rezultacie sugestii, jakie padły ze strony samych funkcjonariuszy

${ }^{1}$ A. Kwieciński, Wykonywanie kary pozbawienia wolności w systemie terapeutycznym, Warszawa 2017. 
w trakcie rozmów poprzedzających przygotowania do projektu badawczego. Po pierwsze, wzorując się na regulacji funkcjonującej już od kilkunastu lat w przestrzeni środków zabezpieczających (Komisja psychiatryczna ds. środków zabezpieczających — art. 201 k.k.w.) zaproponowano utworzenie centralnego podmiotu zajmującego się kierowaniem skazanych do odpowiedniego zakładu karnego. W jego skład wchodziliby fachowcy wybierani spośród zatrudnionych w więziennictwie psychologów, terapeutów i wychowawców. Drugą nowością byłoby oparcie decyzji klasyfikacyjnej bezpośrednio na orzeczeniach ośrodków diagnostycznych.

Tabela 1. Organy kompetentne do wydania początkowej decyzji klasyfikacyjnej (1 przypisano organowi najwłaściwszemu w tym zakresie, a 5 - najmniej kompetentnemu)

\begin{tabular}{|l|c|}
\hline \multicolumn{1}{|c|}{ Organ wydający decyzję } & $\begin{array}{c}\text { Uzyskana } \\
\text { średnia }\end{array}$ \\
\hline Sąd orzekający w trybie art. 62 k.k. & 2,40 \\
\hline Komisja penitencjarna & 2,85 \\
\hline Sąd penitencjarny & 3,74 \\
\hline $\begin{array}{l}\text { Nowy organ centralny (złożony z zatrudnionych } \\
\text { w więziennictwie lekarzy i psychologów) }\end{array}$ & 3,37 \\
\hline Ośrodek diagnostyczny & 2,31 \\
\hline
\end{tabular}

Źródło: opracowanie własne.

O tym, iż wśród praktyków istnieje głębokie przekonanie o potrzebie gruntownych zmian w tym zakresie, świadczy to, że jako najbardziej pożądaną ze względu na potrzeby klasyfikacji skazanych wskazano propozycję stworzenia nowego mechanizmu polegającego na szerszym wykorzystaniu w tym celu ośrodków diagnostycznych. Nieco mniej wskazań specjalistów uzyskał sąd orzekający ${ }^{2}$, któremu ustawodawca przypisał szerokie kompetencje w zakresie klasyfikacji na podstawie art. 62 k.k. Kolejne miejsce zajęła komisja penitencjarna, sporo przed nowym centralnym organem klasyfikacyjnym, podczas gdy na ostatnim miejscu uplasował się sąd penitencjarny.

${ }^{2}$ Pojawiły się jednak głosy, iż sąd powinien powoływać biegłych spośród pracowników więziennictwa, gdyż zazwyczaj występujący w sprawach biegli sądowi nie mają pojęcia o funkcjonowaniu więziennych oddziałów terapeutycznych. 
Tabela 2. Ocena kierunków reformy ośrodków diagnostycznych w relacji do rodzaju placówek, w których zatrudnieni są respondenci

\begin{tabular}{|c|c|c|c|c|c|}
\hline & 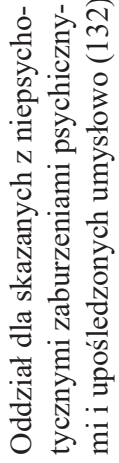 & 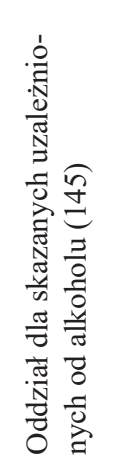 & 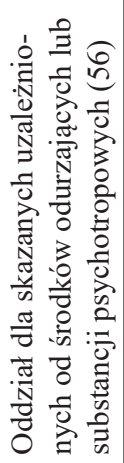 & 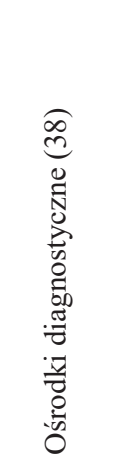 & 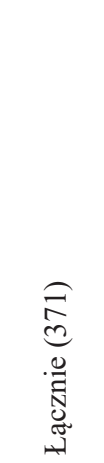 \\
\hline \multirow{2}{*}{$\begin{array}{l}\text { Nie, nie ma potrzeby dokonywa- } \\
\text { nia zmian w ich funkcjonowaniu } \\
\text { i regulacji prawnej }\end{array}$} & 70 & 38 & 17 & 11 & 136 \\
\hline & $53,03 \%$ & $26,20 \%$ & $30,35 \%$ & $28,94 \%$ & $36,65 \%$ \\
\hline \multirow{2}{*}{$\begin{array}{l}\text { Tak, jeśli zmiany te polegałyby } \\
\text { na przejęciu przez te ośrodki } \\
\text { całości diagnozowania psycholo- } \\
\text { giczno-psychiatrycznego w po- } \\
\text { stępowaniu wykonawczym }\end{array}$} & 44 & 59 & 19 & 4 & 126 \\
\hline & $33,33 \%$ & $40,68 \%$ & $33,92 \%$ & $10,52 \%$ & $33,96 \%$ \\
\hline \multirow{2}{*}{$\begin{array}{l}\text { Tak, z podziałem, zgodnie z któ- } \\
\text { rym do ośrodków trafiałyby } \\
\text { przypadki szczególnie skompli- } \\
\text { kowane, reszta zaś diagnoz by- } \\
\text { łaby realizowana w jednostkach } \\
\text { podstawowych }\end{array}$} & 18 & 48 & 20 & 23 & 109 \\
\hline & $13,63 \%$ & $33,10 \%$ & $35,71 \%$ & $60,52 \%$ & $29,38 \%$ \\
\hline
\end{tabular}

Źródło: opracowanie własne.

Wskazanie ośrodków diagnostycznych jako najbardziej kompetentnego organu w zakresie klasyfikacji skazanych czyniło zasadnym postawienie pytania o ocenę obecnej kondycji tych placówek i sformułowanie wniosków co do ich ewentualnej reformy. Odpowiedzi zawiera tabela 2 ich rozkład jednoznacznie potwierdza trafność pozycjonowania ośrodków w roli centralnego organu klasyfikacyjnego, przynajmniej w kontekście przypadków trudnych i skomplikowanych. Potrzebę znaczących zmian w funkcjonowaniu tej instytucji zgłasza łącznie 63,34\% respondentów. 
Równocześnie warto zauważyć, że tak silne wzmocnienie kompetencji (a jednocześnie obciążenie dodatkowymi obowiązkami) znajduje zrozumienie wśród 71,04\% personelu ośrodków diagnostycznych. Te dane dobrze rokują potencjalnej transformacji tych placówek.

Głosy specjalistów popierających potrzebę reformy ośrodków co do zakresu zmian organizacyjnych i prawnych rozkładają się niemal po równo - 33,96\% wszystkich ankietowanych uznało, że konieczne są głębokie zmiany. Według nich ośrodki zajęłyby się całością diagnozy osób skazanych na karę pozbawienia wolności. Założeniem takiego rozwiązania byłoby, aby wstępną selekcję skazanych do takiej diagnozy w miarę możliwości przeprowadzali zatrudnieni w jednostkach podstawowych psychologowie ogólnopenitencjarni oraz przeszkoleni wychowawcy. Niewiele mniej osób biorących udział w badaniach $(29,38 \%)$ opowiedziało się za poszerzonym zakresem kompetencji ośrodków diagnostycznych (jednak nieco węższym niż w pierwszej koncepcji), który polegałby na tym, aby w ramach jasnego podziału zadań kierować do nich tylko przypadki szczególnie skomplikowane. Podobnie jak w ramach pierwszego pomysłu wymagane byłoby włączenie w system diagnozowania jednostek podstawowych, które stałyby się ogniwem typowania trudnych przypadków do ośrodków diagnostycznych.

W dalszej kolejności analizie poddano problem zasadności umieszczania w zakładzie karnym typu zamkniętego wszystkich skazanych $\mathrm{z}$ niepsychotycznymi zaburzeniami psychicznymi ( $\mathrm{w}$ tym z zaburzeniami preferencji seksualnych) i upośledzonych umysłowo. Takie rozwiązanie ustawodawca, na zasadnie obowiązku, wprowadził do Kodeksu karnego wykonawczego w 2011 roku (art. $88 \S 3$ pkt 3 k.k.w. zastąpił dawny art. $88 \S 5$ b k.k.w.). Konstrukcja tego rodzaju od początku była w nauce postrzegana jako kontrowersyjna i odczytywano ją w kategoriach nadmiernej represyjności prawa. Mimo że dotyczy tylko tak zwanej wstępnej klasyfikacji (skazany w wyniku zmiany decyzji klasyfikacyjnej może zostać przeniesiony do jednostki innego typu), uważa się ją za przejaw ograniczania inicjatywy organów klasyfikacyjnych, a tym samym zamach na kluczowe w prawie karnym wykonawczym zasady indywidualizacji i wolnej progresji. 
Tabela 3. Opinie na temat osadzania skazanych w zakładzie karnym typu zamkniętego w trybie art. $88 \S 3$ pkt 3 k.k.w. w relacji do rodzaju placówek, w których zatrudnieni są respondenci

\begin{tabular}{|c|c|c|c|c|c|}
\hline & 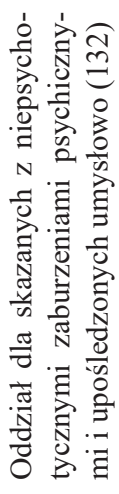 & 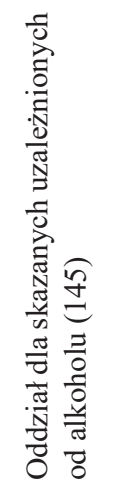 & 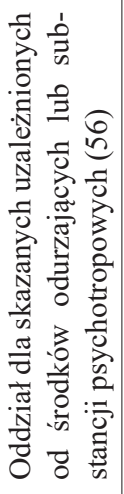 & 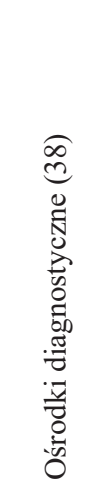 & 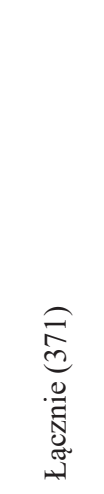 \\
\hline \multirow{2}{*}{$\begin{array}{l}\text { Tak, takie osadzenie powinno } \\
\text { dotyczyć całej kary }\end{array}$} & 84 & 49 & 23 & 14 & 170 \\
\hline & $63,63 \%$ & $33,79 \%$ & $41,07 \%$ & $36,84 \%$ & $45,82 \%$ \\
\hline \multirow{2}{*}{$\begin{array}{l}\text { Tak, ale jedynie na początku } \\
\text { pobytu w zakładzie karnym }\end{array}$} & 33 & 55 & 22 & 16 & 126 \\
\hline & $25,00 \%$ & $37,93 \%$ & $39,28 \%$ & $42,10 \%$ & $33,96 \%$ \\
\hline \multirow{2}{*}{$\begin{array}{l}\text { Nie, kwestię tę należy oddać } \\
\text { w ręce organu klasyfikacyjnego }\end{array}$} & 15 & 41 & 11 & 8 & 75 \\
\hline & $11,36 \%$ & $28,27 \%$ & $19,64 \%$ & $21,05 \%$ & $20,21 \%$ \\
\hline
\end{tabular}

Źródło: opracowanie własne.

Wyniki badań także w tym punkcie zaskakują. Nie dziwi, że co trzeci badany zgadza się z regulacją zawartą w art. $88 \S 3$ pkt 3 k.k.w. (motywując to tym, iż umożliwia ona rozpoznanie realnego stopnia zagrożenia ze strony tej grupy skazanych oraz ich potrzeb, a w rezultacie zmianę decyzji klasyfikacyjnej na dalszych etapach postępowania). Z pewnością natomiast musi zastanawiać, iż aż 45,82\% respondentów uważa, że umieszczenie skazanych z dysfunkcjami zdrowia psychicznego w zakładzie typu zamkniętego w czasie całego pobytu w zakładzie karnym jest niezbędne, gdyż są oni szczególnie trudną ze względów bezpieczeństwa i zachowania kategorią osadzonych. Tylko co piąty specjalista $(20,21 \%)$ sądzi, że dysponentem całości decyzji w tej kwestii powinien pozostawać organ klasyfikacyjny, który w razie potrzeby może zasięgać opinii psychologa. 
Tabela 4. Ocena koncepcji rozlokowania skazanych z zaburzeniami psychicznymi i uzależnionych w relacji do rodzaju placówki, w której zatrudnieni są respondenci

\begin{tabular}{|c|c|c|c|c|c|}
\hline & 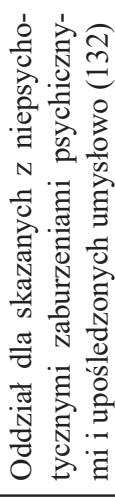 & 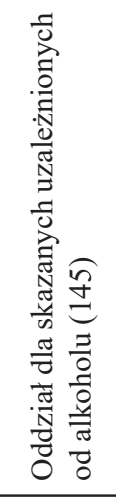 & 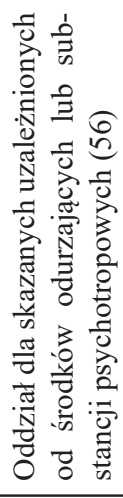 & 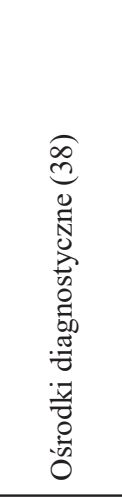 & 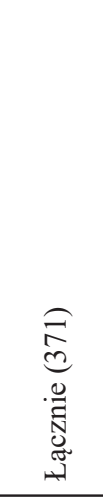 \\
\hline \multirow{2}{*}{$\begin{array}{l}\text { Stworzenie sieci samodzielnych } \\
\text { jednostek o wyraźnym profilu } \\
\text { leczniczo-terapeutycznym, bez } \\
\text { powiązania lub z luźnymi związ- } \\
\text { kami z więziennictwem }\end{array}$} & 26 & 34 & 13 & 5 & 78 \\
\hline & $19,69 \%$ & $23,45 \%$ & $23,21 \%$ & $13,15 \%$ & $21,02 \%$ \\
\hline \multirow{2}{*}{$\begin{array}{l}\text { Wydzielenie odrębnego rodzaju } \\
\text { zakładów karnych dla tych kate- } \\
\text { gorii skazanych (to jest w k.k.w. } \\
\text { z } 1969 \text { roku) }\end{array}$} & 12 & 15 & 7 & 7 & 41 \\
\hline & $9,09 \%$ & $10,34 \%$ & $12,50 \%$ & $18,42 \%$ & $11,05 \%$ \\
\hline \multirow{2}{*}{$\begin{array}{l}\text { Rozrzedzenie ich wśród całej } \\
\text { populacji więziennej i stoso- } \\
\text { wanie zindywidualizowanych } \\
\text { środków terapeutycznych } \\
\text { i wychowawczych }\end{array}$} & 6 & 6 & 3 & 1 & 16 \\
\hline & $4,54 \%$ & $4,13 \%$ & $5,35 \%$ & $2,63 \%$ & $4,31 \%$ \\
\hline \multirow{2}{*}{$\begin{array}{l}\text { Skoncentrowanie tej kategorii } \\
\text { skazanych w oddziałach terapeu- } \\
\text { tycznych o określonej specjaliza- } \\
\text { cji (stan obecny) }\end{array}$} & 88 & 90 & 33 & 25 & 236 \\
\hline & $66,66 \%$ & $62,06 \%$ & $58,92 \%$ & $65,78 \%$ & $63,61 \%$ \\
\hline
\end{tabular}

Źródło: opracowanie własne.

Wraz z ustaleniem potrzeby wydzielenia w osobną grupę klasyfikacyjną i poddania specjalnemu traktowaniu kolejnej kategorii skazanych na karę pozbawienia wolności pojawia się problem ich umiejscowienia w obrębie już ukształtowanego systemu penitencjarnego. Z racji specjalizacji respondentów postanowiono wykorzystać ich doświadczenie 
i wiedzę do oceny różnych modeli organizacji pobytu skazanych wymagających odrębnego traktowania terapeutycznego. Rozwiązania podane w kwestionariuszu skierowanym do zakładów karnych nie były przypadkowe. Ocenie respondentów przedłożono bowiem najważniejsze z funkcjonujących w Polsce w ostatnim stuleciu rozwiązań, włączywszy w to obecnie obowiązujący system.

To właśnie model organizacji terapii oparty na specjalistycznych oddziałach przypisanych czterem podstawowym kategoriom dysfunkcji zdrowotnych zyskał największe poparcie badanych $(63,61 \% \text { wskazań })^{3}$. Tak wysoki wynik należy uznać za deklarację poparcia personelu specjalistycznego dla funkcjonowania systemu terapeutycznego realizowanego w profesjonalnych, sprofilowanych do tego celu placówkach w ramach resortu sprawiedliwości. Interesujące jest zarazem to, że spory odsetek respondentów $(21,02 \%)$ poparł przedwojenną wizję urządzenia działalności leczniczo-terapeutycznej. Według niej zakłady realizujące te zadania miałyby znaczną samodzielność i jednoznacznie leczniczo-terapeutyczny profil, z cywilną ochroną oraz kierownictwem i personelem złożonym wyłącznie z psychologów i lekarzy. Zakładano przy tym ich luźne powiązanie lub nawet całkowitą niezależność od struktur więziennictwa. Dużo mniej głosów $(11,05 \%)$ zdobyła wizja odrębnego rodzaju zakładów karnych przeznaczonych dla skazanych wymagających stosowania szczególnych środków leczniczo-wychowawczych, będąca w gruncie rzeczy powrotem do rozwiązań funkcjonujących w Kodeksie karnym wykonawczym z 1969 roku. Jednocześnie tylko 4,31\% specjalistów zadeklarowało, że najlepszą formą organizacji postępowania z tą grupą będzie umieszczenie przynależących do niej osób w zwykłych oddziałach z równoczesnym stosowaniem zindywidualizowanych środków oddziaływań. To wyraźny brak zaufania dla forsowanej przez centralne władze więzienne koncepcji działalności terapeutycznej realizowanej w sposób półprofesjonalny, czyli w formule systemu terapeutycznego funkcjonującego poza oddziałami specjalistycznymi, zwłaszcza jako krótka interwencja i terapia krótkoterminowa.

${ }^{3}$ Kilka odpowiedzi wskazujących obecne rozwiązanie zostało opatrzonych warunkiem, że istniejące oddziały terapeutyczne powinny podlegać dalszej specjalizacji (zwłaszcza w obrębie oddziałów dla osób z zaburzeniami psychicznymi). 
Tabela 5. Ocena trafności regulacji art. $96 \S 4$ k.k.w. w relacji do miejsca zatrudnienia respondentów

\begin{tabular}{|c|c|c|c|c|c|}
\hline & 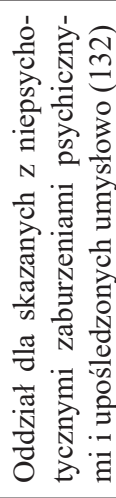 & 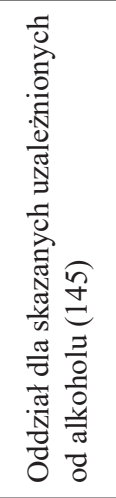 & 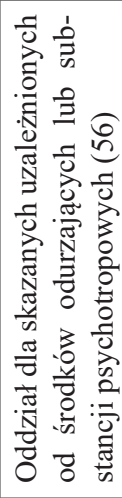 & 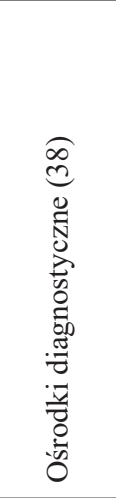 & 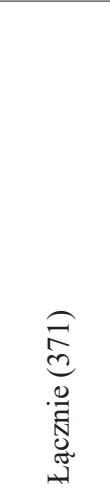 \\
\hline \multirow{2}{*}{$\begin{array}{l}\text { Karę w tym systemie powinno } \\
\text { się wykonywać tylko w oddziale } \\
\text { terapeutycznym }\end{array}$} & 52 & 54 & 20 & 14 & 140 \\
\hline & $39,39 \%$ & $37,24 \%$ & $35,71 \%$ & $36,84 \%$ & $37,73 \%$ \\
\hline \multirow{2}{*}{$\begin{array}{l}\text { Dopuszczalna jest możliwość } \\
\text { wykonywania kary także poza } \\
\text { oddziałem terapeutycznym, } \\
\text { ale tylko w ściśle określonych } \\
\text { przypadkach }\end{array}$} & 60 & 68 & 25 & 17 & 170 \\
\hline & $45,45 \%$ & $46,89 \%$ & $44,64 \%$ & $44,73 \%$ & $45,82 \%$ \\
\hline \multirow{2}{*}{$\begin{array}{l}\text { Dopuszczalna jest możliwość } \\
\text { wykonywania kary także poza } \\
\text { oddziałem terapeutycznym, } \\
\text { ale tylko wobec skazanych } \\
\text { uzależnionych }\end{array}$} & 20 & 23 & 11 & 7 & 61 \\
\hline & $15,15 \%$ & $15,86 \%$ & $19,64 \%$ & $18,42 \%$ & $16,44 \%$ \\
\hline
\end{tabular}

Źródło: opracowanie własne.

Respondentów zapytano również o ich opinię na temat funkcjonowania w praktyce art. $96 \S 4$ k.k.w. Przepis ten stanowi, iż karę pozbawienia wolności w systemie terapeutycznym wykonuje się przede wszystkim w oddziale terapeutycznym o określonej specjalizacji. To ważne ustalenie w zakresie tak zwanej wewnętrznej klasyfikacji, zwłaszcza w obliczu polityki prowadzonej przez administrację penitencjarną, która w ocenie wielu specjalistów niesie z sobą ryzyko nadużyć oraz fikcji terapeutycznej. 
Aż w 37,73\% odpowiedzi kategorycznie przeciwstawiono się jakimkolwiek odstępstwom od tego, aby kara w systemie terapeutycznym była wykonywana poza jednym z oddziałów specjalistycznych. Respondenci często dodawali, że odstępstwa od tej zasady są niedopuszczalne, a taka terapia realizowana poza oddziałem jest zubożona i mniej profesjonalna. Jednocześnie tylko 16,44\% pytanych opowiada się za realizowanym obecnie na szerszą skalę modelem systemu terapeutycznego poza oddziałami terapeutycznymi (tak zwana krótka interwencja i terapia krótkoterminowa), w której wypadku akty rangi podustawowej zezwalają na udział jedynie alkoholików i narkomanów w limitowanej w czasie terapii. Wprawdzie w oficjalnych wypowiedziach takie konstrukcje uzasadniano specyfiką i potrzebami terapeutycznymi tych grup skazanych, niemniej jednak respondenci mający bagaż praktycznych doświadczeń w tej mierze nie podzielają tego optymizmu urzędników.

Znacznie więcej badanych $(45,82 \%)$ dopuszczałoby formułę kompromisową. Miałaby ona polegać na organizacji terapii poza oddziałem w ściśle uzasadnionych przypadkach, z rozszerzeniem jej na wszystkie grupy skazanych z tego systemu. Kwalifikacja określonych przypadków do takiej terapii następowałaby mocą decyzji psychologa pod warunkiem powierzenia jej realizacji profesjonalnemu personelowi. Z dopisków pojawiających się przy tym pytaniu wynika bowiem, że nie wszyscy skazani są predysponowani do tej formy oddziaływań.

Wcześniejsza analiza dotycząca terapii poza oddziałem specjalistycznym wymusza konieczność zajęcia się w ramach zagadnień klasyfikacyjnych tak zwaną krótką interwencją i terapią krótkoterminową. Programy te, zbudowane z myślą o skazanych uzależnionych, pomyślane były jako elementy systemu terapeutycznego, które mają być realizowane poza strukturą więziennych oddziałów terapeutycznych. Warunkiem dopuszczenia takiej działalności jest zastrzeżenie, że będzie ona prowadzona przez „odpowiednio przeszkolony personel”. Mimo tego wobec tej formuły terapii podnoszone są poważne zarzuty, zarówno w nauce, jak i wśród praktyków.

Respondentom w ramach tego pytania zaproponowano nie tylko wskazanie najlepszej w ich opinii konstrukcji prowadzenia tego rodzaju programów odwykowych (w ramach dostępnych już rozwiązań); mogli też dokonać oceny zasadności ich prowadzenia w więziennictwie. Bli- 
Tabela 6. Ocena realizacji zadań terapeutycznych wobec skazanych uzależnionych w ramach programów tak zwanej krótkiej interwencji i terapii krótkoterminowej w relacji do miejsca zatrudnienia i zajmowanego stanowiska przez respondentów

\begin{tabular}{|c|c|c|c|c|c|c|c|c|c|c|c|}
\hline & \multicolumn{2}{|c|}{ 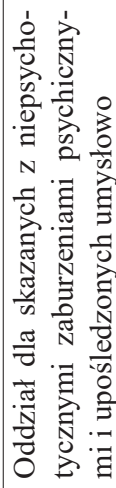 } & \multicolumn{2}{|c|}{ 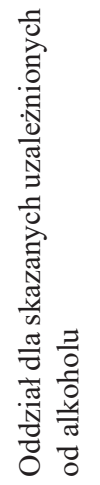 } & \multicolumn{2}{|c|}{ 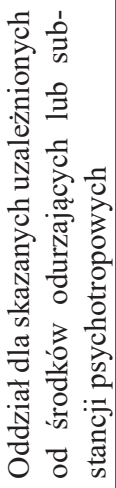 } & \multicolumn{2}{|c|}{ 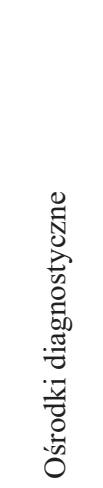 } & \multicolumn{3}{|c|}{ 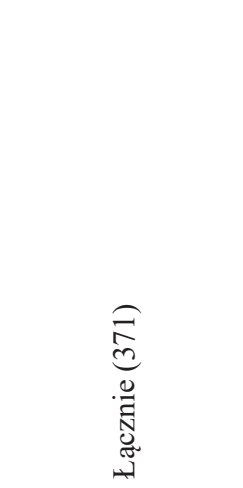 } \\
\hline & $\mathrm{P}$ & $\mathrm{W}$ & $\mathrm{P}$ & $\mathrm{W}$ & $\mathrm{P}$ & $\mathrm{W}$ & $\mathrm{P}$ & W & $\mathrm{P}$ & W & Suma \\
\hline $\begin{array}{l}\text { System terapeutyczny } \\
\text { poza oddziałem terapeu- } \\
\text { tycznym (stan obecny) }\end{array}$ & 16 & 26 & 22 & 28 & 8 & 12 & 5 & 2 & 51 & 68 & $\begin{array}{c}119 \\
(32,07 \%)\end{array}$ \\
\hline $\begin{array}{l}\text { System terapeutyczny } \\
\text { w oddziale terapeu- } \\
\text { tycznym, odpowiednio } \\
\text { dla alkoholików lub } \\
\text { narkomanów }\end{array}$ & 9 & 15 & 4 & 12 & 2 & 2 & 3 & 2 & 18 & 31 & $\begin{array}{c}49 \\
(13,20 \%)\end{array}$ \\
\hline $\begin{array}{l}\text { Odpowiednio system zwy- } \\
\text { kły lub programowanego } \\
\text { oddziaływania }\end{array}$ & 24 & 12 & 17 & 28 & 12 & 9 & 12 & 1 & 65 & 50 & $\begin{array}{c}115 \\
(30,99 \%)\end{array}$ \\
\hline $\begin{array}{l}\text { Terapia odwykowa prowa- } \\
\text { dzona w tej formule jest } \\
\text { nieefektywna niezależnie } \\
\text { od miejsca realizacji }\end{array}$ & 17 & 13 & 9 & 25 & 3 & 8 & 12 & 1 & 41 & 47 & $\begin{array}{c}88 \\
(23,71 \%)\end{array}$ \\
\hline
\end{tabular}

$\mathrm{P}$ - psycholodzy; W - wychowawcy.

Źródło: opracowanie własne.

sko jedna trzecia ankietowanych jest zadowolona $\mathrm{z}$ istniejących $\mathrm{w}$ tym zakresie rozwiązań organizacyjnych i prawnych. Jednocześnie jednak prawie co czwarty $(23,71 \%)$ ankietowany uważa, że te nowe instytucje w praktyce nie przeszły „testu efektywności”. Nie widzą także dla nich szans na przyszłość, niezależnie od miejsca ich realizacji. Duży odsetek 
specjalistów (30,99\%), którzy opowiedzieli się za dalszym funkcjonowaniem tych form terapii, dostrzega potrzebę głębokich zmian w umiejscowieniu tych mechanizmów w ramach systemu penitencjarnego. Proponuje się uniezależnienie tych programów od systemu terapeutycznego i realizacji ich głównych założeń w ramach systemu zwykłego lub programowanego oddziaływania pod kontrolą psychologa penitencjarnego lub odpowiednio przeszkolonego wychowawcy. Szczególnie dużo uwag respondenci kierują pod adresem tak zwanych krótkich interwencji, zwłaszcza praktyki ich realizacji przez personel bez odpowiedniego przeszkolenia; niekiedy zarzucają im wręcz podtrzymywanie fikcji pracy ze skazanym z problemem uzależnienia. Wśród ankietowanych pojawiły się również głosy $(13,20 \%)$ sugerujące potrzebę włączenia terapii krótkoterminowej i krótkiej interwencji do programów oddziałów terapeutycznych dla uzależnionych.

Tabela 7. Ocena koncepcji wydzielenia skazanych niepełnosprawnych fizycznie w odrębną grupę klasyfikacyjną i przeznaczenie dla nich jednego typu oddziałów terapeutycznych

\begin{tabular}{|l|c|c|}
\hline & Liczba wskazań & Odsetek wskazań \\
\hline $\begin{array}{l}\text { Rozwiązanie zasadne, wynikające } \\
\text { z potrzeby stosowania środków } \\
\text { terapeutycznych w ramach systemu } \\
\text { terapeutycznego }\end{array}$ & 80 & $21,56 \%$ \\
\hline $\begin{array}{l}\text { Posunięcie zbędne; wystarczy } \\
\text { dostosować architektonicznie niektóre } \\
\text { jednostki penitencjarne, a skazanym } \\
\text { zapewnić doraźną opiekę lekarską } \\
\text { i rehabilitacyjną oraz pomoc zdrowych } \\
\text { skazanych }\end{array}$ & 291 & $78,43 \%$ \\
\hline
\end{tabular}

Źródło: opracowanie własne.

W kolejnym punkcie badań uznano za wskazane, aby zasięgnąć opinii praktyków w przedmiocie tego, jak powinno w przyszłości wyglądać postępowanie z osadzonymi niepełnosprawnymi fizycznie. Tylko co piąty ankietowany jest zwolennikiem utrzymania obecnych rozwiązań formalno-prawnych w tym zakresie. Należy dodać, że wszyscy ankietowani są świadomi tego, iż zapowiadane już w 1997 roku powstanie 
samodzielnych oddziałów terapeutycznych dla skazanych z tego rodzaju niepełnosprawnościami nie miało miejsca i nie zanosi się w najbliższym czasie, by takie placówki miały zostać utworzone.

Zdecydowana większość zatrudnionych w oddziałach terapeutycznych i ośrodkach diagnostycznych $(78,43 \%)$ zauważa jednak potrzebę zmiany obowiązującej sytuacji niepełnosprawnych skazanych. Uznali oni, iż wystarczająca będzie przebudowa wybranych zakładów karnych tak, aby stały się dopasowane do potrzeb tych osób i objęcie ich doraźną opieką rehabilitacyjną i lekarską. Spełnienie tej propozycji będzie oznaczać, że skazani z tej grupy nie będą korzystać ze zinstytucjonalizowanej formy systemu terapeutycznego (oddziałów specjalistycznych). Będą mogli odbywać karę w innych systemach, gdzie następowałaby ich integracja ze zdrowymi skazanymi, ewentualnie skorzystają $\mathrm{z}$ formy pozaoddziałowej systemu terapeutycznego. To ważne ustalenie z pozycji zmian procedury klasyfikacyjnej.

Kwestią nierozerwalnie związaną z procesem klasyfikacji jest problem kolejki oczekujących na przyjęcie do oddziałów terapeutycznych. Wynika on z niewspółmierności oferowanych w oddziałach terapeutycznych miejsc w stosunku do istniejących w tym zakresie potrzeb. Powoduje to sytuację, w której osoby zakwalifikowane do systemu terapeutycznego pozostają w nim w formule pozaoddziałowej. Dochodzą także głosy, iż niekiedy organy klasyfikujące wstrzymują się z wydaniem decyzji kierującej tam skazanego w oczekiwaniu na wolne miejsce w placówce specjalistycznej określonego typu. To wszystko powoduje, że naturalne jest pytanie o pierwszeństwo przyjęć do specjalistycznego oddziału określonych grup skazanych, zwłaszcza kiedy z góry wiadomo, że niektórych z nich nie uda się objąć specjalistyczną terapią do końca kary.

W obliczu tych uwarunkowań respondentów poproszono o wskazanie grup, które ich zdaniem powinny korzystać z pierwszeństwa przyjęć do takich placówek ${ }^{4}$. Najwięcej wskazań dotyczyło skazanych podejmujących terapię dobrowolnie. Na kolejnych miejscach umieszczano ska-

${ }^{4}$ Chodziło o to, aby wskazać, w jaki sposób doraźnie zaspokajać potrzeby związane z kolejką oczekujących na terapię. Pod uwagę wzięto nawet zmianę kategoryzacji oddziałów terapeutycznych (M, P, R) w zależności od wskazania przez terapeutów priorytetów w terapii określonych grup skazanych (recydywistów, pierwszy raz odbywających karę czy też młodocianych). 
Tabela 8. Pierwszeństwo przyjęć do oddziału terapeutycznego poszczególnych grup skazanych w sytuacji długiego czasu oczekiwania na miejsce w relacji do miejsca zatrudnienia respondentów (w pytaniu należało uszeregować odpowiedzi od 1 do 10 , gdzie 1 oznacza przyjęcie w pierwszej kolejności, a 10 - w ostatniej)

\begin{tabular}{|c|c|c|c|c|c|}
\hline & 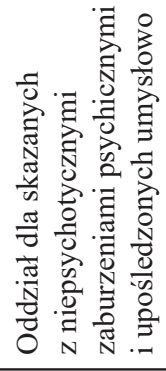 & 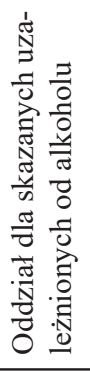 & 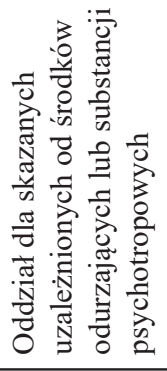 & 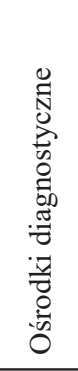 & 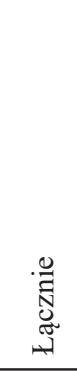 \\
\hline Młodocianych & 4,98 & 4,28 & 4,33 & 4,18 & 4,53 \\
\hline Recydywistów & 8,35 & 7,17 & 7,50 & 6,86 & 7,60 \\
\hline Skazanych po raz pierwszy & 5,97 & 4,62 & 4,76 & 5,63 & 5,22 \\
\hline Skazanych na kary najkrótsze & 5,84 & 3,16 & 3,72 & 5,15 & 4,39 \\
\hline $\begin{array}{l}\text { Skazanych za określone rodzaje } \\
\text { przestępstw (przeciwko życiu } \\
\text { i zdrowiu, wolności seksualnej } \\
\text { i obyczajności, bezpieczeń- } \\
\text { stwu powszechnemu, rodzinie } \\
\text { i opiece) }\end{array}$ & 4,52 & 5,94 & 6,27 & 5,24 & 5,41 \\
\hline $\begin{array}{l}Z \text { orzeczonym jednocześnie } \\
\text { środkiem zabezpieczającym, } \\
\text { wykonywanym po karze }\end{array}$ & 6,38 & 7,14 & 7,12 & 7,46 & 6,89 \\
\hline $\begin{array}{l}\text { Podczas pobytu w ZK zagraża- } \\
\text { jących swojemu życiu i zdrowiu } \\
\text { lub życiu i zdrowiu innych }\end{array}$ & 4,41 & 6,55 & 6,74 & 5,33 & 5,69 \\
\hline $\begin{array}{l}\text { Skazanych skierowanych przez } \\
\text { sąd w trybie art. } 62 \text { k.k. lub } 117 \\
\text { k.k.w. }\end{array}$ & 4,54 & 6,55 & 6,52 & 5,48 & 5,71 \\
\hline $\begin{array}{l}\text { Skazanych ujawniających trud- } \\
\text { ności adaptacyjne do warunków } \\
\text { więziennych }\end{array}$ & 3,93 & 5,55 & 4,79 & 4,84 & 4,79 \\
\hline $\begin{array}{l}\text { Podejmujących terapię } \\
\text { dobrowolnie }\end{array}$ & 5,23 & 3,38 & 2,81 & 3,42 & 3,95 \\
\hline
\end{tabular}

Źródło: opracowanie własne. 
zanych na kary krótkie, młodocianych oraz karanych po raz pierwszy. Zapewne odmienne przesłanki towarzyszyły uprzywilejowaniu osób, które ujawniają trudności adaptacyjne do warunków więziennych, oraz tych, które zagrażają życiu i zdrowiu swojemu oraz innych. Na ostatnich miejscach znaleźli się recydywiści, osoby z orzeczonym środkiem zabezpieczającym oraz skierowani do systemu terapeutycznego w trybie art. 62 k.k. lub 117 k.k.w. Zdaniem kilku respondentów najbardziej optymalnym rozwiązaniem (sprawiedliwym i pozwalającym zachować względny porządek pracy) będzie przyjmowanie skazanych na terapię według kolejności zgłoszeń do oddziałów.

Tabela 9. Ocena rozwiązania polegającego na ustalonym odgórnie czasie pobytu w oddziale terapeutycznym w relacji do miejsca zatrudnienia ankietowanych

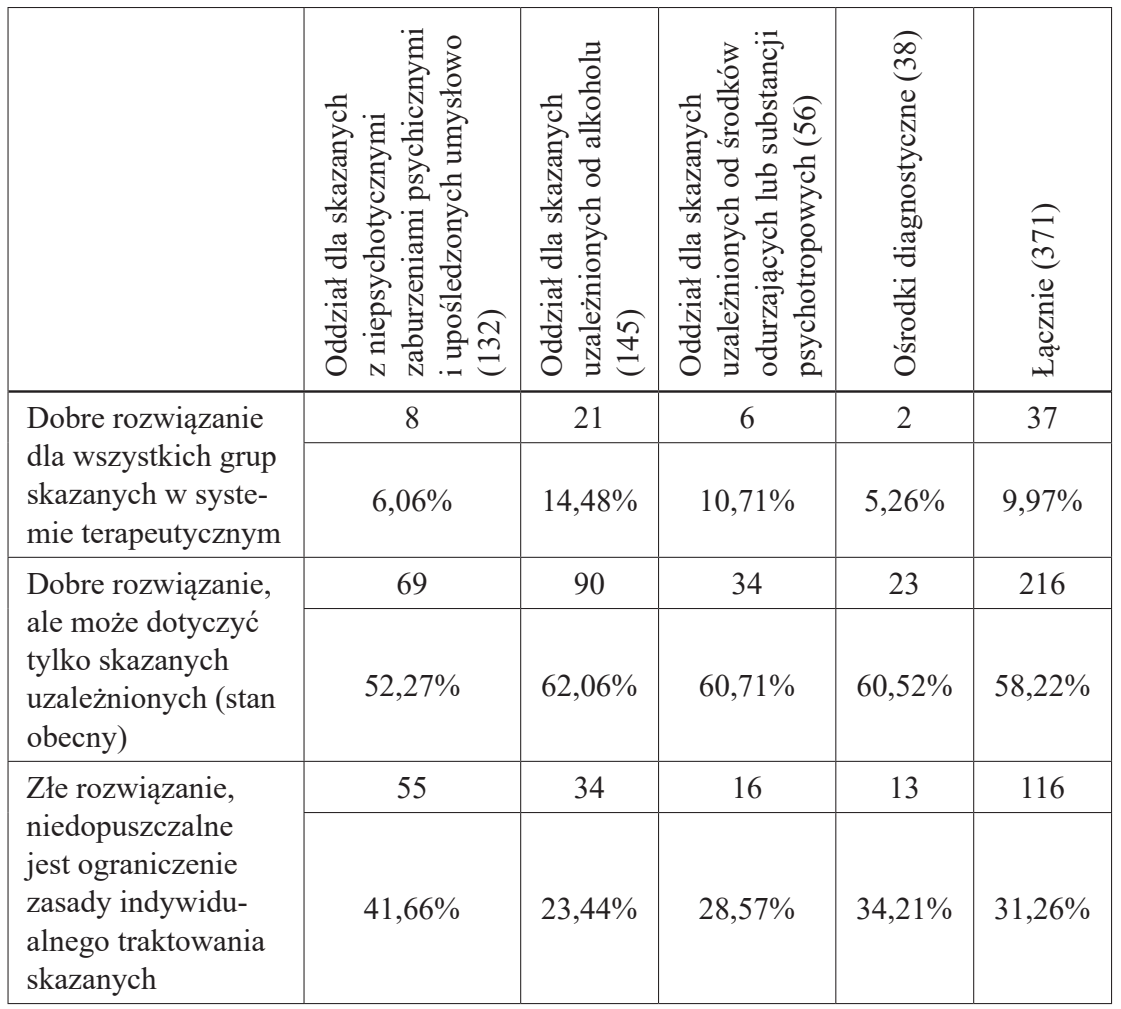

Źródło: opracowanie własne. 
Od początku w systemie terapeutycznym obowiązywała zasada czasowego pobytu w nim skazanych. Oznaczało to tyle, że skazany miał pozostawać tam do czasu, kiedy wymagał oddziaływań specjalistycznych, zwłaszcza opieki psychologicznej, lekarskiej lub rehabilitacyjnej (art. 97 $\S 3$ k.k.w.). Następnie był przenoszony do innego, właściwego systemu wykonania kary. W praktyce kodeksowa zasada temporalnego pobytu była, zwłaszcza w stosunku do skazanych uzależnionych, omijana. Powodów tego stanu rzeczy było wiele — do najważniejszych niewątpliwie należy zaliczyć wysokie koszty organizacji oddziałów specjalistycznych i związaną z tym małą dostępność miejsc w takich placówkach.

Ankietowanych specjalistów poproszono następnie o ustosunkowanie się do zasady przechodniości. Ponad połowa $(58,22 \%)$ akceptuje obecną praktykę zakreślania z góry czasu pobytu w oddziałach terapeutycznych dla skazanych uzależnionych. Argumentują, że jest to rozwiązanie racjonalne i dopuszczalne $\mathrm{z}$ racji możliwości określenia zarówno u alkoholików, jak i narkomanów z góry wymaganego czasu terapii. Jednocześnie prawie wszyscy badani mają świadomość tego, iż ograniczona w czasie terapia nie jest dobra dla wszystkich skazanych w systemie terapeutycznym — tylko 9,97\% ankietowanych jest za rozciągnięciem tej możliwości, co umożliwiłoby jak najszerszy dostęp do terapii więziennej. Warto dodać, iż co trzeci specjalista (31,26\%) nie zgadza się z obecną praktyką. Argumentują, że długość leczenia może być skorelowana jedynie z potrzebami konkretnego osadzonego i nie może być ustalana z góry.

Uzyskane w wyniku badań rezultaty mogą stanowić asumpt do szerszej dyskusji nad potrzebą i kierunkami zmian w procesie klasyfikacji skazanych. Należy przy tym pamiętać, że efekty właściwie zaprojektowanego procesu rozmieszczania skazanych w jednostkach penitencjarnych rzutują na przebieg i skuteczność działalności wychowawczej i terapeutycznej realizowanej w trakcie odbywania kary pozbawienia wolności. Mimo że badany obszar objął zaledwie wycinek złożonego zagadnienia, jakim jest klasyfikacja skazanych, to wydaje się, iż pole eksploracji badawczej było nader istotne z punktu widzenia tego procesu.

Po pierwsze, działalność terapeutyczna więziennictwa, zwłaszcza jeśli włączymy w to kwestie badań osobopoznawczych, jest niezwykle ważnym ogniwem systemu klasyfikacji. Właściwe zdiagnozowanie i za- 
kwalifikowanie skazanego do systemu terapii bezpośrednio bowiem rzutuje na osiągnięcie celów wykonywania kary w stosunku do tej jednej z najtrudniejszych grup skazanych, jaką są osadzeni z systemu terapeutycznego. Po drugie, przestrzeń ta po 1997 roku rzadko była przedmiotem szerszych badań, tym bardziej ogólnopolskich. Po trzecie, specjalizacja i doświadczenie respondentów dostarczają poważnych argumentów do oceny i ewentualnej reformy kluczowych z punktu widzenia klasyfikacji instytucji prawa karnego wykonawczego.

Wnioski, jakie można sformułować na podstawie udzielonych przez specjalistów odpowiedzi, są wyjątkowo ciekawe. Spora ich część znajduje pokrycie w toczącej się w nauce dyskusji. Do takich ustaleń trzeba z pewnością zaliczyć niską ocenę dotychczasowej praktyki klasyfikacyjnej, w której rolę zasadniczego organu klasyfikacyjnego odgrywa komisja penitencjarna (a uzupełniająco sąd penitencjarny) przy zupełnie biernym stanowisku sądu meriti (art. 62 k.k.). Dostrzeżono także potrzebę wzmocnienia organizacyjnego i kompetencyjnego ośrodków diagnostycznych, które dziś realizują stosunkowo wąski zakres zadań w zakresie diagnostyki psychologicznej i psychiatrycznej. Kontrowersyjną kwestią pozostaje sprawa zróżnicowanej typologii placówek terapeutycznych więziennictwa. Na tym polu widać znaczą polaryzację poglądów specjalistów. Jednocześnie optymizm musi wzbudzać wysoka ocena obecnej organizacji terapii w formule systemu terapeutycznego. Ankietowani, prowadzący na co dzień oddziaływania specjalistyczne, wyrażają w ten sposób swoje zaufanie do takiego urządzenia tych oddziaływań, co pozwala na ich udoskonalanie z zachowaniem obecnych podstaw takiej konstrukcji. Wskazują na przepisy, które są nadużywane w procesie klasyfikacji i terapii skazanych, jak choćby art. $96 \S 4$ k.k.w., pozwalający na wykonywanie kary w systemie terapeutycznym poza oddziałem specjalistycznym. Potwierdzają się tym samym zarzuty o uprawianie w ten sposób fikcji terapeutycznej i sztucznej poprawie statystyk. W ocenie ankietowanych problemem pozostają także programy doraźnej interwencji dla skazanych uzależnionych. W swoich odpowiedziach starają się nie tyle poddać je krytyce, ile znaleźć dla nich odpowiednie miejsce w systemie penitencjarnym. Podobna sytuacja ma miejsce w odniesieniu do skazanych niepełnosprawnych fizycznie. Wydzielenie ich w odrębną grupę klasyfikacyjną i przypisanie do systemu terapeutycznego zostało po latach ocenione przez 
respondentów jako błąd. W swoich odpowiedziach ankietowani specjaliści próbowali dać również rozwiązania doraźne na trapiące więziennictwo od wielu lat problemy, jak choćby wskazanie pierwszeństwa terapii dla niektórych grup w związku z długim czasem oczekiwania na terapię.

\section{Bibliografia}

Kwieciński A., Wykonywanie kary pozbawienia wolności w systemie terapeutycznym, Warszawa 2017.

\section{Selected problems of penitentiary classification in the perception of specialist staff}

Summary

This paper focuses on the problems of penitentiary classification of particular groups of convicts, which include convicts with mental disorders, addicts, and those suffering from physical health dysfunctions. The conclusions presented in the paper are based on the answers given by specialists (doctors, psychologists, therapists, educators) employed in prisons. They conclusions can be an incentive for discussion on the reform of the system of putting convicts in prison units appropriate for their needs, which in turn determines the results in terms of therapeutic and penitentiary influence and thus achieving the goals of penalty by convicts.

Keywords: penitentiary classification, imprisonment sentence, therapy, diagnostic centre. 